Article

\title{
The Impact of Program Participation on Rural Household Income: Evidence from China's Whole Village Poverty Alleviation Program
}

\author{
Junying Lin ${ }^{1,2}$, Zhonggen Zhang ${ }^{2, *}$ and Lingli $\mathrm{Lv}^{3}$ \\ 1 School of Management, Zhejiang University, Hangzhou 310058, China; 11520070@zju.edu.cn \\ 2 China Academy for Rural Development, Zhejiang University, Hangzhou 310058, China \\ 3 Business School, Guangxi University, Nanning 530004, China; bole8901@163.com \\ * Correspondence: zhgzhang@zju.edu.cn
}

Received: 22 February 2019; Accepted: 8 March 2019; Published: 14 March 2019

check for updates

\begin{abstract}
Villagers' participation in poverty alleviation programs has received considerable attention, especially with regard to the poor. However, not much is known about the welfare effect of villagers' program participation. This paper analyzes the impact of villagers' program participation on their incomes. We used household data from 529 villagers in China's Whole Village Poverty Alleviation Program. We focused on two types of program participation-discussion and voting. Using the propensity score matching approach, we estimate the impact of rural households' program participation on their income. The results show that the education and the political career of the household head determine program participation. Households participating in discussion and voting have a positive and significant effect on household income. Richer households benefit more from the program. However, the poor receive less benefits. We conclude that broadening villager's participation can boost the effectiveness of China's poverty alleviation program.
\end{abstract}

Keywords: poverty reduction; propensity score matching; poor households

\section{Introduction}

Reducing poverty has been the major task of the government to improve social development [1-3], boost economic growth [4-6] and benefit individual welfare [7-10]. According to the World Bank [11], the population of people living in poverty decreased from $35 \%$ in 1990 to $11 \%$ in 2013. [1]. However, the population of the poor remains high. Therefore, it is urgent to target the poor and improve poor household benefits, though the income share of poor households is dwindling [4,11,12].

Existing evidence finds that poverty alleviation programs have at least three positive effects, including improving the well-being of the poor [13-15], increasing community participation [16] and stabilizing household income [17-19]. The findings of Christiaensen, et al. [20] indicate that participating in agricultural activities can reduce poverty among the poorest of the poor. Regarding to the income effect of poverty alleviation programs, Phan, et al. [21] found that the Vietnam pro-poor program had a positive effect on income inequality, but that it has no significant effect on poverty incidence. Using matching methods, Park and Wang [22] found that China's poor village investment program did not increase poorer household income while it increased the income of richer households from $6.1 \%$ to $9.2 \%$. Ding, Qin and Shi [7] also found that microfinance projects, led by the government, can increase household income level significantly and positively. They also find that democratic villages with less political connections to the local government get more benefits [7]. Thus, there is limited literature on identifying the effects of the different types of participation behaviors on household income. 
However, the effect of the program on rural households is unclear. First, various studies have argued whether the poor will be targeted since sometimes the poorest cannot get the subsidies provided by the government $[17,23]$. Second, seldom do the poor have a chance to access poverty programs, although the projects are designed to target the poor [24]. Third, the impact of poverty alleviation is affected by the susceptibility to capture elites or the village leader [22]. Some studies, for example, community-driven development programs in the Philippines, do not benefit the poor although the project improves the average household income $[17,18]$. In addition, as mentioned by the International Monetary Fund, low-level coverage of programs, the multiple objectives involved and reliance on subsidies are additional reasons for social assistance program failure.

As for program participation, existing literature focuses on different participation behaviors. Voting and voice, as types of civil participation, can improve the well-being of participants. Wossen, et al. [25] suggested that farmers' access to technology information can lead to a $4.6 \%$ reduction in poverty. Boulding and Wampler [13] found that citizens can vote to select programs via meetings, and benefiting from the elected programs. Liu, et al. [26] also found that households can receive more income after participating in a land transfer program. Kosec and Wantchekon [27] found that information with individual incentives can improve rural governance and service delivery. In such a case, villagers' participating in discussion with information exchange can subsequently improve individual welfare. However, there is limited literature on combining these two types of participation behaviors on household income, especially in rural districts.

In this article, we first analyze factors that determine households' participating discussion and voting using the bivariate probit model. Next, we chose the propensity score matching (PSM) to estimate the welfare effect of participation in program voting and discussion.

This paper makes three contributions: First, we focus on four conditions of program participations using the PSM approach, which is the first application on rural household participation in poverty alleviation programs. Second, we evaluate the effect of poverty alleviation programs by using unique household data collected from poor villages in China. Since poor household data are hard to collect, there is not much empirical evidence purely based rural households located in the poor areas of China. Third, we also examine distributional aspects, comparing elite and non-elite households and poor and rich households, adding to existing literature on the benefit distribution differences between different subjects.

The rest of this paper is organized as follows. Section 2 presents the research background. Section 3 describes the data collection, and Section 4 details the empirical strategy. Section 5 presents the empirical results, followed by discussion in Section 6 and a conclusion in Section 7.

\section{Background}

\subsection{China's Poverty Alleviation Program}

In China, poverty alleviation programs and policies are administered by multiple-agencies, including various government agencies and non-governmental organizations (NGOs). Some international NGO programs in poor areas, such as Action Aid, are targeting the old, women and the young, depending on their program design. However, Chinese government programs are motivated by decentralization to alleviate the poor. In addition, the government also wants to boost village resources via by infrastructure construction, providing agricultural subsidies, building primary schools and establishing free village book houses.

The Whole Village Poverty Alleviation Program (WVPAP) is one program among the programs initiated by the Chinese government to target the poor in designated villages. The primary goal of the WVPAP is to improve the infrastructure quantity and quality including village roads, bridges, dams, sanitary facilities and other aspects. Poor villages are selected by the government from the poor village lists, which are selected according to a weighted poverty index based on eight indicators [22]. For each 
WVPAP poor village, the local government gave each village more than two million RMB Yuan in total in the five years after 2012.

The WVPAP provides opportunities to villagers who participate in the program. They can, for example, vote to select infrastructure projects as community members. They vote for the program selection according to their household and community demand, such as voting for village road construction that can eliminate the inconvenience of walking on muddy roads during the rainy seasons. Moreover, they can also discuss the program via village meetings to get more knowledge about their community affairs.

\subsection{Program Participation and Household Income}

Existing literature has found a positive effect of participation in poverty alleviation programs on household income $[28,29]$. In China, villagers can benefit from the program in different ways. Under the WVPAP program, villagers can, for instance, vote to select projects in each of the designated poor villages [22]. In addition, they can also participate in village meetings in group discussions to voice their opinions. We distinguish program discussion and voting to analyze the effect of villager participation in community affairs on their incomes.

On the one hand, participating in project discussions may have an impact on household income. Before the program is approved and initialized, villagers can attend village meetings, discussions, and exchange information. They can voice their requirements of the projects that will be implemented in their community, guaranteeing the quality of the infrastructure programs. Therefore, household may benefit from participating program discussion with increasing income.

On the other hand, in relation to the program voting process, a large body of literature argues that the impact of targeting the poor may be affected by elites or other interest groups [30] since villagers may not participate in choosing their favored programs to serve their own interests [24]. Voting for the program, as a type of democratic participation, can create opportunities for villagers to select their favored infrastructure projects, benefiting their family and community. Therefore, voting as participatory democracy may increase their well-being [13].

We are particularly interested in whether the villager participate in both procedures. Those who obtain more information via internal discussions are more likely to participate in program voting. A possible explanation is that villagers are more active in providing their assistance, for example, by voting to select a program benefiting their community. One study found that farmers who both vote and get information on land co-management receive more benefit [26]. Thus, we expect a positive joint effect of project discussion and voting on household income.

\section{Data Collection}

In this article, we used the rural household data from Guangxi Province collected in 2014. The survey took place from 15th June to 30th August in 2014, with the help of the local government. Firstly, we conducted a pre-survey for the rural households in Xingye County, a designated poor county, to adjust and make our questionnaire more accurate given the real conditions of the China poverty alleviation program. Next, we conducted the survey using the corrected questionnaire after the pre-survey. We used multistage sampling to collect household level data. Of the countries, 15 designated counties were randomly chosen from the total 64 designated poor counties in Guangxi province; approximately one quarter of all counties in Guangxi are included in this survey. In each county, we randomly selected 4 designated villages that belong to the national Whole Village Poverty Alleviation Program (WVPAP). Finally, in each selected village, 20 households including program participants and non-participants were randomly selected.

Our questionnaire covers topics including household characteristics, farm characteristics, program participation and community development. After eliminating missing information, we collected information on 529 farm households. 


\section{Empirical Strategy}

In this paper, we wanted to identify the effect of a villager's program participation on their household income. Specifically, two types of program participation were identified. One is villager participation in voting for program selection. The other is discussion, defined as villagers voicing their ideas about the program in village meetings. However, neither voting nor discussion is random; they are determined by some factors. Therefore, we used propensity score matching (PSM) to establish an appropriate counterfactual.

We chose the PSM approach to estimate the impact of program participation with restrictions stemming from observed exogenous factors. These factors had an impact on the sample falling into the treatment group or its counterpart group. After estimating the probability for selection into the treatment group, we can calculate the impact of program participation on household income.

Table 1 shows the aggregated households for different types of program participation. Discussion means households' participation in village meetings to voice their ideas. More than $50 \%$ of households chose program discussion. Voting equals one, which means that the household votes to select a program. The results show that 141 households participate in program voting, accounting for $27 \%$ of the total sample. In addition, more than one quarter of the total households (119 households) chose both program decisions.

Table 1. Aggregated Households by Different Types of Participation.

\begin{tabular}{cccc}
\hline Different Program Participation & Voting $=\mathbf{1}$ & Voting $=\mathbf{0}$ & Total \\
\hline Discussion $=1$ & Type One (T1) $=119$ & Type Two (T2) $=173$ & 292 \\
Discussion $=0$ & Type Three (T3) $=22$ & Type Four (T4) $=215$ & 237 \\
Total & 141 & 388 & 529 \\
\hline
\end{tabular}

Source: Authors' calculations.

\subsection{Determinants of Program Participation}

To estimate the determinants of a households' participation in poverty alleviation programs, we chose the bivariate probit model. Using the bivariate probit model, we could identify two different types of decision making, assuming two decisions are correlated. The model is defined as follows:

$$
\begin{gathered}
\text { Discussion }^{*}=\alpha_{0}+\alpha_{i} X_{i}+\varepsilon_{1} ; \text { Discussion }=1 \text { if Discussion } * 0 \\
\text { Voting }^{*}=\beta_{0}+\beta_{i} X_{i}+\varepsilon_{2} ; \text { Voting }=1 \text { if Voting }{ }^{*}>0 \\
\operatorname{Cov}\left(\varepsilon_{1}, \varepsilon_{2}\right)=\rho
\end{gathered}
$$

where Discussion* and Voting* represent the utility of the households' participating discussion and voting; when Discussion* exceeds zero, it represents that the household engages in program discussion; Voting*, a dummy variable, indicates that the households participates in the program voting if it exceeds zero; $\alpha_{i}$ and $\beta_{i}$ are parameters to be estimated; $\alpha_{0}$ and $\beta_{0}$ are constant; $\varepsilon_{1}$ and $\varepsilon_{2}$ are error terms; $\rho$ is the covariance of $\varepsilon_{1}$ and $\varepsilon_{2}$, representing the correlation between Discussion* and Voting*. If the two decisions are independent, the zero value of $\rho$ is taken, which means that the standard probit model is sufficient for estimating the determinants of the two decisions. If their correlation $\rho$ is significantly different from zero, the bivariate probit model is used to estimate the determinants of household decisions.

\subsection{The Impact of Program Participation on Household Income}

Following Lechner [31], we used the propensity score matching (PSM) approach to estimate the impact of program participation on household income. Compared to the ordinary least squares 
(OLS) model, we can control for the impact of an observed factor and solve the selection bias of program participation:

$$
P_{j}(\hat{x}) ; j \in J=\{\mathrm{a}, \mathrm{b}, \mathrm{c}, \mathrm{d}\}
$$

Then the pair-wise propensity scores were calculated as:

$$
\hat{P}^{j \mid j, m}(x)=\frac{P_{j}(x)}{P_{j}(x) \hat{+} P_{m}(x)} ; \Delta j \neq m
$$

where $j$ and $\mathrm{m}$ belong to the context set $J=\{\mathrm{a}, \mathrm{b}, \mathrm{c}, \mathrm{d}\}$, which may include individual cases or combinations of different situations; and $\left.\hat{P}\right|^{j \mid j, m}(x)$ represents the predicted conditional propensity score of a villager participating in the situation $j$ for the situation $m$. In this study, we assessed the impact of two types of program participation-discussion and voting, compared to nonparticipants. Thus, we were also interested in estimating the combined effect of participating in two programs, or only one program excluding participation in the other program. We then estimated the average treatment effect for the treated (ATT) as follows:

$$
A T T^{j \mid m}=E\left\{Y_{j}-Y_{m} \mid J=j\right\} ; \Delta j \neq m
$$

We chose the nearest neighbor (NN) matching algorithm to form statistical twins [32]. Additionally, we also selected five matching partners and limited matching within the common support to improve the matching quality. We also used $t$-tests to analyze the difference between the participants and nonparticipants.

\subsection{Variable Chosen for Matching}

As noted in existing literature, the variables for the matching approach have an impact on program participation rather than on outcomes [22,33]. In this article, we chose the total household income as the outcome variable. It is defined as the yearly household income in 2014, including agricultural income and nonagricultural income.

We first control variables that are associated with households' program participation and their incomes (Table 2). Household head age, gender, and education are controlled because younger, male and educated household heads are more active in community co-management [26,34]. Younger and educated household heads are more likely to own more human capital [35]. As noted by Schultz and Schultz [36], human capital can improve people's abilities to perceive, interpret, and respond to affairs. Therefore, they are more likely to participate in voting and discussions to voice their opinions. Male household heads are more active in community affairs whereas in rural China females are not confident to voice their views.

Household size and family labor represent labor availability, meaning a larger family with more power and surplus labor is more likely to participate in community affairs. Consistent with previous studies, family size and household labor tend to affect households' participation positively. Household land area is also controlled, since more land may guarantee agricultural activities in the village. Households with more land assets are more likely to influence household community participation [37].

Second, we are particularly interested in how village cadres play a role in community management since elite capture has been frequently discussed in the literature $[23,34,38,39]$. For example, Zhang, Giles and Rozelle [38] show that village cadres with elite capture are more active in community participation and Vargas, Lo, Rohde and Howes [39] finds that traditional leaders attend public affairs with more group discussions. Households identified as poor are also controlled. Some evidence finds that poor households are less likely to participate in community affairs because they are less educated. Additionally, we also controlled for communist party membership because households with political 
ties influence village affairs based on their own interest $[2,40]$. Therefore, household heads with a party membership identity are more likely to participate in discussions and voting.

Table 2. Variable Description and Definition.

\begin{tabular}{ll}
\hline \multicolumn{1}{c}{ Variables } & \multicolumn{1}{c}{ Definition } \\
\hline $\begin{array}{l}\text { Age of household head } \\
\text { Male of household head }\end{array}$ & Age of household head (years) \\
Education of household head & $\begin{array}{l}\text { Ed the household head is male; otherwise }=0 \\
\text { school; } 3=\text { middle school; } 4=\text { high school; } 5=\text { college }\end{array}$ \\
Family size & Number of people living in the household \\
Cadre & 1 if the household head is village cadre; otherwise $=0$ \\
Family labor & Number of family members living in the household \\
Land area & Agricultural land that the household owns $(\mathrm{mu})$ \\
Poverty & 1 if the household head belongs to the registered poor population; \\
Party membership & otherwise = 0 \\
Village population & 1 if the household head is a party member; otherwise $=0$ \\
& Number of people living in the village \\
\hline
\end{tabular}

Third, village characteristics were also controlled. Villages with larger populations may have more participants. Therefore, we controlled for village size because larger villages may receive more financial support. This may have an impact on villagers' program participation and their total incomes.

\section{Results}

\subsection{Descriptive Statistics}

Table 3 demonstrates the mean difference between participants and non-participants for different conditions of the sampled households. The results in Table 3 show that some variables are significant while some are not significant. Educated household heads are more likely to participate in both decisions because educated household heads have more social capital and are more likely to participate in community affairs. Additionally, households with political affiliation are more likely to engage in program voting. Moreover, the results in the last column of Table 3 show that educated wealthier households with more household labor were more likely to vote to select a program. We also found that households with communist party membership tended to vote for project selection. However, the results in Table 3 also suggest that households registered as poor are less likely to participate in program voting.

Table 3. Mean Differences in the Selected Explanatory Variables between Participants and Nonparticipants.

\begin{tabular}{lcccccc}
\hline \multirow{2}{*}{ Variables } & \multicolumn{3}{c}{ Discussion } & \multicolumn{3}{c}{ Voting } \\
\cline { 2 - 7 } & Yes & No & Difference & Yes & No & Difference \\
\hline Age of household head & 48.911 & 48.363 & 0.548 & 48.830 & 48.606 & 0.224 \\
Male of household head & 0.644 & 0.624 & 0.019 & 0.667 & 0.624 & 0.043 \\
Education of household head & 3.253 & 2.949 & $0.304^{* * *}$ & 3.440 & 3.000 & $0.440^{* * *}$ \\
Family size & 5.264 & 5.165 & 0.099 & 5.064 & 5.276 & -0.212 \\
Cadre & 0.387 & 0.194 & $0.193 * * *$ & 0.511 & 0.224 & $0.286^{* * *}$ \\
Family labor & 3.377 & 3.186 & 0.191 & 3.383 & 3.258 & 0.125 \\
Land area & 11.761 & 11.377 & 0.384 & 13.973 & 10.722 & $3.251^{* *}$ \\
Poverty & 0.479 & 0.515 & -0.035 & 0.383 & 0.536 & $-0.153^{* * *}$ \\
Party membership & 0.521 & 0.338 & $0.183 * * *$ & 0.589 & 0.384 & $0.205^{* * *}$ \\
Village population & 0.777 & 0.797 & -0.02 & 0.794 & 0.784 & 0.011 \\
Total & 292 & 237 & & 141 & 388 & \\
\hline
\end{tabular}

Coefficients followed by ${ }^{* *}$, and ${ }^{* * *}$ indicate significance at the $5 \%$ and $1 \%$ level respectively. 
To analyze the income difference in program participation, we calculate the mean household income for different types of participants and non-participants, including discussion, voting, both conditions, only discussion and only voting. Table 4 demonstrates the main results and compares the different conditions. The results show that households that participate in neither voting nor discussions received the lowest income. However, households that participate in both discussions and voting received the highest income. Participants in discussions have more income on average than their counterparts, similar to the results for participants and non-participants for program voting.

Table 4. Mean Income of Different Types of Program Participation.

\begin{tabular}{lcc}
\hline \multicolumn{1}{c}{ Type of Program Participation } & Obs. & Mean Income (Thousand RMB Yuan) \\
\hline Discussion $=1$ (T1 and T2) & 292 & 34.561 \\
Discussion $=0$ (T3 and T4) & 237 & 20.404 \\
Voting $=1$ (T1 and T3) & 141 & 43.084 \\
Voting $=0$ (T2 and T4) & 388 & 22.816 \\
Discussion $=1$, Voting $=1$ (T1) & 119 & 43.098 \\
Discussion $=1$, Voting $=0$ (T2) & 173 & 28.689 \\
Discussion $=0$, Voting $=1$ (T3) & 22 & 43.008 \\
Discussion $=0$, Voting $=0$ (T4) & 215 & 18.091 \\
\hline
\end{tabular}

Source: Authors' calculations; One RMB Yuan was equal to 0.163 US dollars in 2014.

\subsection{Determinants of Households' Program Participation}

The results in Table 5 show the determinants of household participation in program discussion (Column 2) and program voting (Column 3) using a bivariate probit model. We also report the results using the probit model of discussion and voting respectively presented in the last two column of Table 5. Though the two models show similar results with the same coefficients and direction, the covariance of the error terms in the bivariate probit model, $\rho$, is 59.304, and significantly different from zero. Therefore, we report the estimates from the bivariate probit model.

Table 5. Determinants of Household Program Participation (Bivariate Probit Model and Probit Model).

\begin{tabular}{|c|c|c|c|c|c|c|c|c|}
\hline \multirow{3}{*}{ Variables } & \multicolumn{4}{|c|}{ Bivariate Probit Model } & \multicolumn{4}{|c|}{ Probit Model } \\
\hline & \multicolumn{2}{|c|}{ Discussion } & \multicolumn{2}{|c|}{ Voting } & \multicolumn{2}{|c|}{ Discussion } & \multicolumn{2}{|c|}{ Voting } \\
\hline & Coefficients & S.E. & Coefficients & S.E. & Coefficients & S.E. & Coefficients & S.E. \\
\hline Age of household head & 0.002 & $(0.006)$ & 0.001 & $(0.007)$ & 0.002 & $(0.006)$ & 0.001 & $(0.006)$ \\
\hline Male of household head & 0.003 & $(0.119)$ & 0.006 & $(0.133)$ & -0.007 & $(0.119)$ & 0.026 & $(0.132)$ \\
\hline Education of household head & $0.107^{*}$ & $(0.055)$ & $0.112 *$ & $(0.059)$ & 0.105 * & $(0.055)$ & $0.108 *$ & $(0.060)$ \\
\hline Family size & -0.009 & $(0.037)$ & $-0.079 *$ & $(0.043)$ & -0.007 & $(0.038)$ & $-0.075 *$ & $(0.043)$ \\
\hline Cadre & $0.400 * * *$ & $(0.129)$ & $0.598^{* * *}$ & $(0.136)$ & $0.406^{* * *}$ & $(0.131)$ & $0.613^{* * *}$ & $(0.141)$ \\
\hline Family labor & 0.049 & $(0.056)$ & 0.073 & $(0.062)$ & 0.046 & $(0.056)$ & 0.07 & $(0.062)$ \\
\hline Land area & 0.001 & $(0.004)$ & $0.009 * *$ & $(0.004)$ & 0.001 & $(0.004)$ & $0.009 * *$ & $(0.004)$ \\
\hline Poverty & 0.119 & $(0.119)$ & -0.161 & $(0.130)$ & 0.105 & $(0.119)$ & -0.142 & $(0.130)$ \\
\hline Party membership & 0.115 & $(0.102)$ & 0.022 & $(0.108)$ & 0.121 & (0.107) & 0.018 & $(0.114)$ \\
\hline Village population & -0.057 & $(0.137)$ & 0.112 & $(0.151)$ & -0.06 & $(0.137)$ & 0.106 & $(0.152)$ \\
\hline Constant & $-0.602 *$ & $(0.362)$ & $-1.195^{* * *}$ & $(0.400)$ & -0.584 & $(0.362)$ & $-1.196^{* * *}$ & $(0.400)$ \\
\hline
\end{tabular}

Source: Authors' calculations; Coefficients followed by ${ }^{*}, * *$, and ${ }^{* * *}$ indicate significance at the $10 \%, 5 \%$ and $1 \%$ level respectively; Clustered standard errors at the county level are in parentheses.

Household heads with higher education are more likely to choose to participate in program discussion and voting, since more educated people are more active in democratic community activities. During the discussions villagers can obtain more information about the projects that are attractive to them. With more information, villagers can better communicate and exchange their ideas. Regarding to the current situation of their community, they can voice their basic demands. Farm size per household has a positive and significant effect on participation in program voting. This is because households with more assets are more likely to attend collective activities [41].

We also tested for elite capture by examining whether households with a village cadre have a positive effect on household income (Alatas et al., 2012). The results in Table 5 show that in a village 
with people in official occupations, households are more likely to participate in community affairs (Liu et al., 2018). Since most community affairs are initiated by the village cadres. Hence, they have more access to community affairs and are thus more active in community programs [42].

In addition, we also found that households with more family members were less likely to participate in community affairs. The effect was different from zero at $10 \%$ significance. This is in line with earlier literature $[26,43]$, which finds that family size has a negative effect on household participation in program voting. A possible explanation is that if a larger family is engaged in other activities that better support the family's livelihood, the income effect will hinder labor input in joint management activities [44].

\subsection{Impact of Program Participation on Household Income}

Using the propensity scores from the probit model shown in Table 5, we analyzed the impact of program participation on household income. We also calculated the number of treated households on support or off support, whose pair-wise propensity scores fall within the scope or beyond the scope (see Appendix A Table A1). The distribution of pair-wise propensity scores between treated and untreated units is demonstrated in Appendix A, Figures A1-A4. Since several untreated sample households were off support and only a few treated households were on support, we could easily match the treated households with the untreated households but fail to match them in the opposite direction. Therefore, we followed Caliendo, et al. [45], who calculated the average treatment effect on the treated and focused on treated and untreated households that are on-support to analyze the impact of program participation on household income.

The effects of household participation in programs are reported in Table 6. Four types of conditions were considered as follows: program discussion, program voting, both discussion and voting, only discussion and only voting. The results in Table 6 show participation in either program voting or discussion had a positive and significant effect on household income. Households who take part in program discussion received on average 34,561 RMB Yuan per year, which is 13,118 RMB Yuan more than that in the control group. Therefore, participation in discussions can lead to an increase in household income by $61.173 \%$. Households that participated in voting to select a program increased their household income by $62.489 \%$, with an increase of 16,672 RMB Yuan per year.

Table 6. The impact of Program Participation on Household Income (in RMB Thousand Yuan Per Year).

\begin{tabular}{|c|c|c|c|c|c|c|}
\hline Program Participation & Treated & Control & Absolute Difference & Relative Difference & S.E. & T Value \\
\hline Discussion (T1 and T2 against T3 and T4) & 34.561 & 21.444 & 13.118 & 61.173 & 5.854 & 2.480 ** \\
\hline Voting (T1 and $\mathrm{T} 3$ against $\mathrm{T} 2$ and $\mathrm{T} 4$ ) & 43.352 & 26.680 & 16.672 & 62.489 & 8.930 & $1.760 *$ \\
\hline Discussion and Voting (T1 against T4) & 43.200 & 16.815 & 26.385 & 156.913 & 9.254 & $2.850 * * *$ \\
\hline Only Discussion (T2 against T4) & 28.284 & 18.291 & 9.993 & 54.635 & 6.051 & $1.770 *$ \\
\hline Only Voting (T3 against T4) & 44.209 & 20.603 & 23.605 & 114.571 & 18.308 & 1.240 \\
\hline
\end{tabular}

Additionally, we were also interested in the joint effect of household participation in both program voting and discussion. The effect of participation in two programs yielded positive and significant effects on household income, with an increase in household income of 26,385 RMB Yuan. In details, we found that the average income of the treated group was 43,200 RMB Yuan, which exceeded the mean income of the control group by 16,815 RMB Yuan. A possible explanation is that more participation in program decisions can largely help the poor by increasing their income, since our sample households were located in poor areas.

\subsection{Hedogenous Effect}

Though existing literature finds that there is elite capture in program participation [23], households without village cadres may also benefit from program election. In addition, as existing literature has argued, poverty alleviation programs fail to enhance the benefit to poor households $[17,22]$. 
We expected that richer households are more likely to benefit from the program. To test for elite capture and whether the poor receive the benefits from program participation, we used the OLS approach for four subsamples. These included households with village cadre, with no cadre, poor households and rich households.

In line with our expectations, the results in the second column of Table 7 show that households with no cadres that participated in two programs received more income by 11,503 and $24,243 \mathrm{RMB}$ Yuan, respectively. The effect is different from zero at $5 \%$ and $10 \%$ significance. However, we did not find significant marginal effect for households with elites who participate in program discussion. One explanation for the positive and larger marginal effects of voting is that voting can increase participation equality at the village level. Consequently households with no village cadres can receive more income [7].

Table 7. Marginal Effect of Program Participation on Household Income (Subsamples).

\begin{tabular}{|c|c|c|c|c|c|c|c|c|}
\hline Variables & \multicolumn{2}{|c|}{ Households with Cadre } & \multicolumn{2}{|c|}{ Households without Cadre } & \multicolumn{2}{|c|}{ Poor Households } & \multicolumn{2}{|c|}{ Rich Households } \\
\hline Discussion & $\begin{array}{c}4.332 \\
(9.325)\end{array}$ & & $\begin{array}{c}11.503^{* *} \\
(5.360)\end{array}$ & & $\begin{array}{c}7.231 \\
(4.925)\end{array}$ & & $\begin{array}{l}13.019 \\
(7.544)\end{array}$ & \\
\hline Voting & & $\begin{array}{l}9.069 * \\
(4.429)\end{array}$ & & $\begin{array}{l}24.243 * \\
(13.748)\end{array}$ & & $\begin{array}{l}-6.975 \\
(8.753)\end{array}$ & & $\begin{array}{l}34.689 * \\
(16.604)\end{array}$ \\
\hline Controls & YES & YES & YES & YES & YES & YES & YES & YES \\
\hline County Dummies & YES & YES & YES & YES & YES & YES & YES & YES \\
\hline Obs. & 155 & 155 & 373 & 373 & 262 & 262 & 267 & 267 \\
\hline
\end{tabular}

Source: Authors' calculations; Coefficients followed by * and ${ }^{* *}$ indicate significance at the $10 \%$ and $5 \%$ level respectively; The table reports average marginal effects. Clustered standard errors at the county level are in parentheses.

We also tested the benefits between the poor and the rich, which are shown in the last two columns of Table 7. The results showed that for rich households, participating in program voting resulted in their income increasing by 34,689 RMB Yuan. The estimations also show the disappointing results for the poor, since they did not benefit from the program. These contrasting results are in line with the literature, which finds that the poor do not benefit from programs and that the richer households are the main beneficiaries $[17,19]$.

\subsection{Robustness Tests}

To test the robustness of our results, we performed two additional analyses using a series of alternative estimations. First, because in only one of the potential outcomes each observed subject may have a missing-data problem [46], we used the inverse-probability-weighted regression adjustment (IPWRA) approach to estimate the impact of program participation on household income. The results in Appendix A, Table A2, are in line with our main results in Table 6.

Second, we chose the OLS approach to analyze the two types of program participation on household income assuming that each program participation is exogenous. The results in Appendix A, Table A3, show that household participation in program voting and discussion may increase household income by 19,058 RMB Yuan and 11,536 RMB Yuan respectively. The results do not change substantially.

\section{Discussion}

Estimation results show that the four types of program participation have a positive effect on household income. The positive influence of program discussion on household income is in line with earlier findings [27]. As noted by Kosec and Wantchekon [27], people with incentives and motivation are more likely to benefit from the programs. This is because more information is provided. In other words, our findings also prove that those in power will tend to act in their own interest and seek to obtain an excess of available benefits [47].

We also found that households participating in both types of activities received the largest income. They can get an income increase of $156.913 \%$, compared to nonparticipants' income. A possible reason 
could be that more participation may increase the equality and transparence of program selection. Therefore, rent seeking may not happen due to information asymmetry. However, households participating in voting only have no significant effect on household income. A possible reason is that the sample size is quite small (see Table 1).

Investigating different subsamples, households with no cadres received more income. This is in line with existing literature, which finds that broader participation can guarantee the equality and transparence of program selection. In addition, richer households benefited more from the program. However, the poor households received less benefits, which supports existing literature on different benefit distributions $[17,22]$.

\section{Conclusions}

Poverty alleviation programs have received great attention worldwide $[8,10,25]$. To target the poor, the Chinese government has invested greatly in community based programs $[1,48]$. However, there is not much empirical research focusing on the welfare effect of villagers' program participation. In this study, we analyzed the impact of villagers' program participation on their household income using a unique Chinese rural household data set.

Estimation results show that villagers' participating in discussion and voting tend to increase their household income by $61.17 \%$ and $62.49 \%$. This finding is in line with existing literature that suggests that pro-poor programs can improve villagers' welfare [22,49]. Second, we also find a positive joint effect of discussion and voting on household income with an increase of approximately $157 \%$. This positive effect suggests that broader villager participation can yield more welfare effects [26]. Third, an investigation of distributional aspects shows that richer villagers received more benefits from the program. This finding suggests that more participation access should be encouraged to improve the welfare effect on villagers, especially the poor [25].

The findings of this study have policy implications. First, the government should encourage villagers' participation in community-based programs. For example, they can provide subsidies to the villagers engaged in village meetings. Second, the government should consider the benefit of the poor. This is because we find the programs are less profitable for the poor. Third, broader participation should be encouraged to improve the transparency of program selection. The government should better program selection procedures and provide more sources to villagers to voice their ideas.

Our study has two limitations. First, we used household income, which is self-reported by the villagers. The income might not be accurate. This is because some agricultural or off-farm income is hard to recall exactly. Second, even though voting and discussion are the main participation, other possible decisions may also have an impact on income. For instance, villagers' participation in follow-up management after program initiation might also be considered.

Author Contributions: It should be noted that the whole work was accomplished by the authors collaboratively. All authors read and approved the final manuscript.

Funding: This study is supported by the Guangxi Science and Technology Department, China (Grant number AB17205005) and the Ministry of Education, China (Grant number 16jjd790053).

Acknowledgments: We are grateful for the comments received from two anonymous reviewers that helped us to improve the paper.

Conflicts of Interest: The authors declare no conflict of interest. 


\section{Appendix A}

Table A1. The on support and off support number of treated households.

\begin{tabular}{lccccc}
\hline & Discussion & Voting & Both Voting and Discussion & Only Discussion & Only Voting \\
\hline On support & 289 & 139 & 118 & 169 & 21 \\
Off support & 3 & 2 & 1 & 4 & 1 \\
\hline
\end{tabular}

Source: Authors' calculations.

Table A2. The Impact of Program Participation on Household Income (IPWRA approach).

\begin{tabular}{lccc}
\hline \multicolumn{1}{c}{ Program Participation } & ATT & Robust S.E. & Z-Statistics \\
\hline Discussion (T1 and T2 against T3 and T4) & 13.072 & 5.407 & $2.42^{* *}$ \\
Vote (T1 and T3 against T2 and T4) & 17.235 & 8.038 & $2.14^{* *}$ \\
Discussion and Vote (T1 against T4) & 23.358 & 9.388 & $2.49^{* * *}$ \\
Only Discussion (T3 against T4) & 9.455 & 5.145 & $1.84 *$ \\
\hline
\end{tabular}

Source: Authors' calculations; Coefficients followed by ${ }^{*}, * *$, and ${ }^{* * *}$ indicate significance at the $10 \%, 5 \%$ and $1 \%$ level respectively.

Table A3. The Impact of Program Participation on Household Income (OLS approach).

\begin{tabular}{lcccc}
\hline \multirow{2}{*}{ Variables } & \multicolumn{3}{c}{ Total Income (Thousand Yuan Per Year) } \\
\cline { 2 - 5 } & Margins & S.D. & Margins & S.D. \\
\hline Discussion & $19.058^{* *}$ & $(8.597)$ & & \\
Voting & & & $11.536^{* *}$ & $(4.526)$ \\
Controls & YES & & YES & \\
County Dummies & YES & YES & \\
Observations & 529 & 529 & \\
\hline
\end{tabular}

Source: Authors' calculations; Coefficients followed by ** indicate significance at the $5 \%$ level respectively; The table reports average marginal effects. Clustered standard errors at the county level are in parentheses.

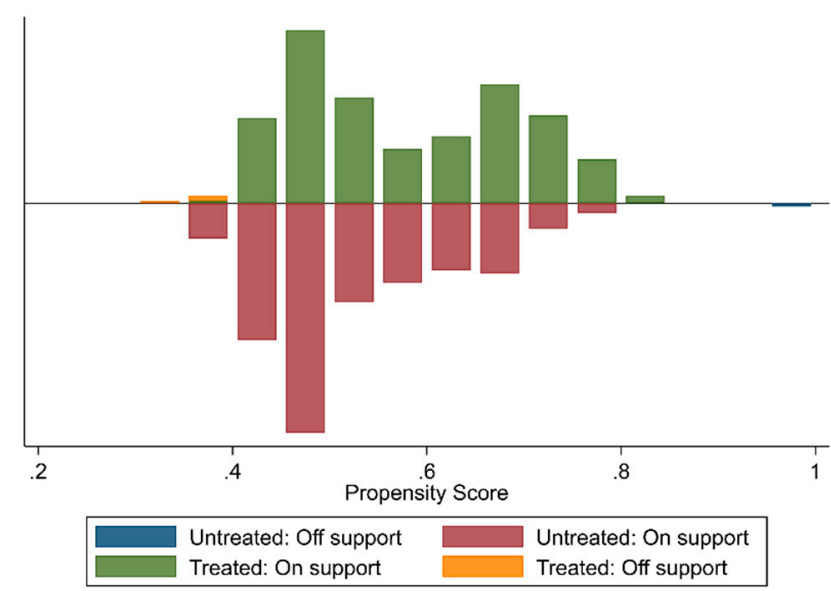

Figure A1. Distribution of propensity scores for treatment and control households (Program voting). 


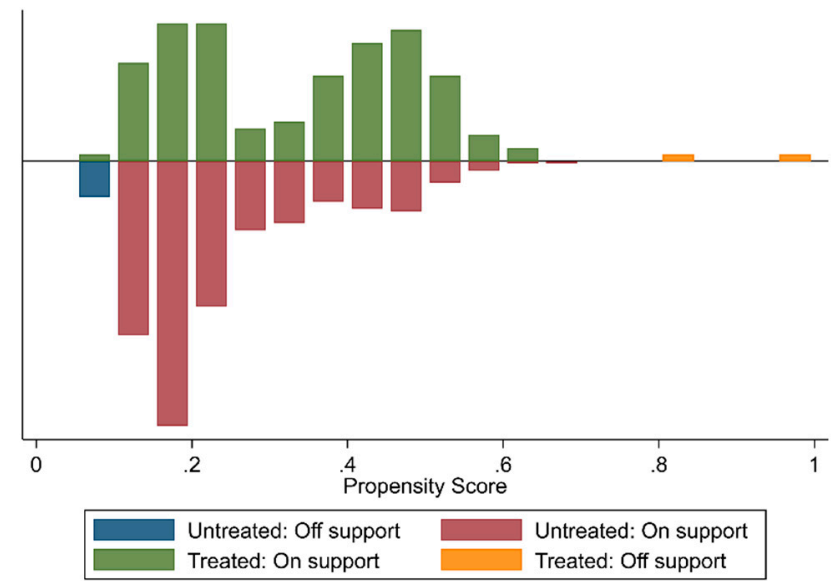

Figure A2. Distribution of propensity scores for treatment and control households (Program discussion).

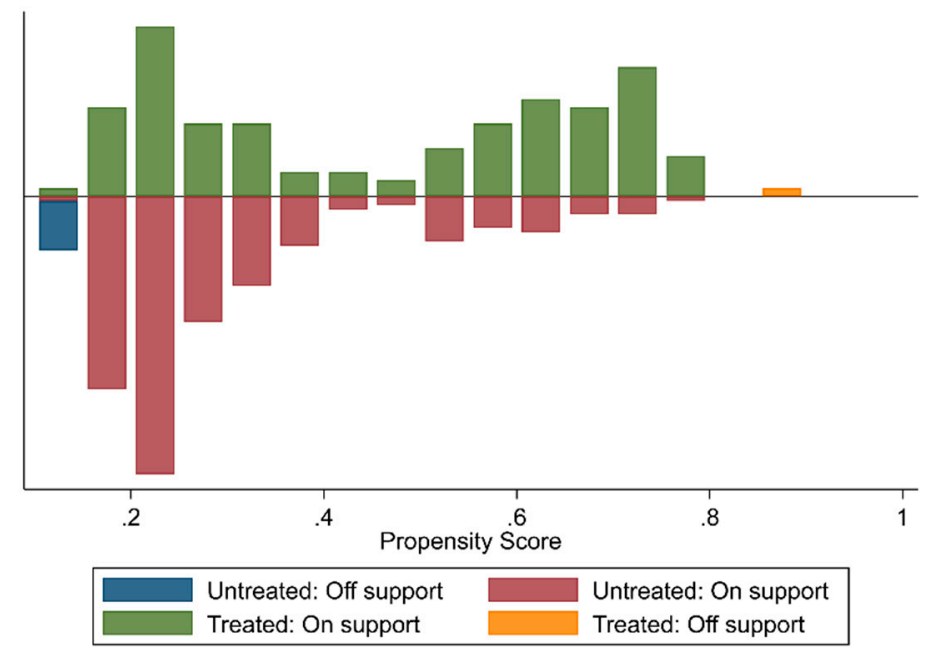

Figure A3. Distribution of propensity scores for treatment and control households (Joint effect of program discussion and voting).

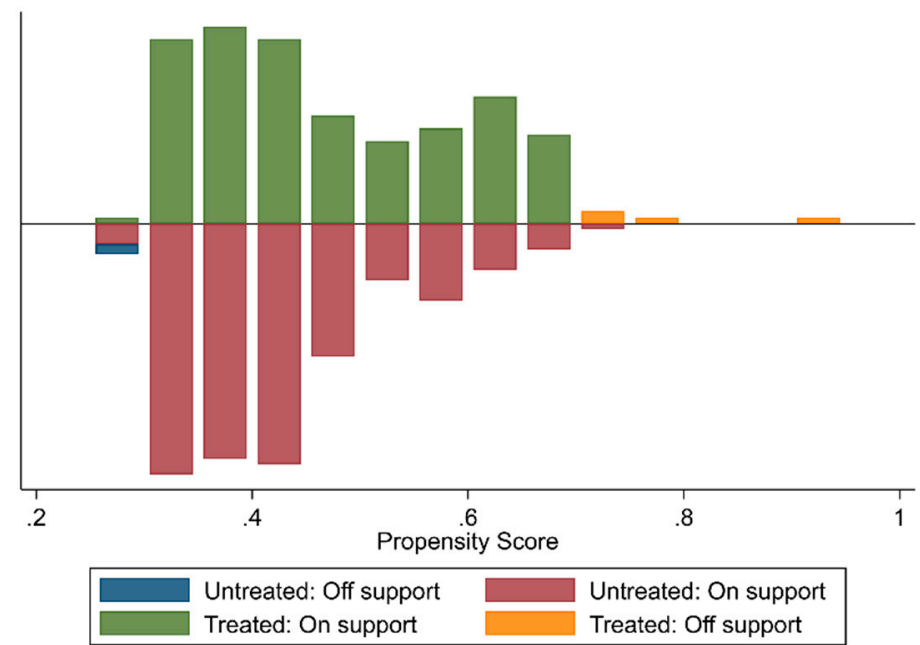

Figure A4. Distribution of propensity scores for treatment and control households (Only program discussion). 


\section{References}

1. Westmore, B. Do government transfers reduce poverty in China? Micro evidence from five regions. China Econ. Rev. 2018, 51, 59-69. [CrossRef]

2. Mansuri, G.; Rao, V. Localizing Development: Does Participation Work? The World Bank: Washington, DC, USA, 2012.

3. Prokopy, L.S. The relationship between participation and project outcomes: Evidence from rural water supply projects in India. World Dev. 2005, 33, 1801-1819. [CrossRef]

4. Westmore, B. Sharing the benefits of China's growth by providing opportunities to all. J. Int. Commer. Econ. Policy 2017, 8, 1750013. [CrossRef]

5. Yang, Z. Threshold Effect of Poverty Alleviation Funds on Human Capital Accumulation: A Case Study of Impoverished Counties in China. Sustainability 2019, 11, 809. [CrossRef]

6. Cruz, M.; Ahmed, S.A. On the impact of demographic change on economic growth and poverty. World Dev. 2018, 105, 95-106. [CrossRef]

7. Ding, H.; Qin, C.; Shi, K. Who benefit from government-led microfinance projects? Evidence from rural China. J. Comp. Econ. 2018, 46, 1253-1272. [CrossRef]

8. Zhou, Y.; Guo, Y.; Liu, Y.; Wu, W.; Li, Y. Targeted poverty alleviation and land policy innovation: Some practice and policy implications from China. Land Use Policy 2018, 74, 53-65. [CrossRef]

9. Ogutu, S.O.; Qaim, M. Commercialization of the small farm sector and multidimensional poverty. World Dev. 2019, 114, 281-293. [CrossRef]

10. Wagle, U.R.; Devkota, S. The impact of foreign remittances on poverty in Nepal: A panel study of household survey data, 1996-2011. World Dev. 2018, 110, 38-50. [CrossRef]

11. Bank, T.W. Poverty and Shared Prosperity 2016: Taking on Inequality; World Bank: Washington, DC, USA, 2016.

12. Kanbur, R.; Wang, Y.; Zhang, X. The Great Chinese Inequality Turnaround; International Food Policy Research Institute (IFPRI): Washington, DC, USA, 2017; Volume 1637.

13. Zhang, H.; Wang, Z.; Liu, J.; Chai, J.; Wei, C. Selection of targeted poverty alleviation policies from the perspective of land resources-environmental carrying capacity. J. Rural Stud. 2019. [CrossRef]

14. Boulding, C.; Wampler, B. Voice, Votes, and Resources: Evaluating the Effect of Participatory Democracy on Well-being. World Dev. 2010, 38, 125-135. [CrossRef]

15. Ainembabazi, J.H.; Abdoulaye, T.; Feleke, S.; Alene, A.; Dontsop-Nguezet, P.M.; Ndayisaba, P.C.; Hicintuka, C.; Mapatano, S.; Manyong, V. Who benefits from which agricultural research-for-development technologies? Evidence from farm household poverty analysis in Central Africa. World Dev. 2018, 108, $28-46$. [CrossRef]

16. Arcand, J.-L.; Wagner, N. Does Community-Driven Development Improve Inclusiveness in Peasant Organizations?-Evidence from Senegal. World Dev. 2016, 78, 105-124. [CrossRef]

17. Saguin, K. Why the poor do not benefit from community-driven development: Lessons from participatory budgeting. World Dev. 2018, 112, 220-232. [CrossRef]

18. Labonne, J.; Chase, R.S. Who is at the Wheel When Communities Drive Development? Evidence from the Philippines. World Dev. 2009, 37, 219-231. [CrossRef]

19. Nkonya, E.; Phillip, D.; Mogues, T.; Pender, J.; Kato, E. Impacts of Community-driven Development Programs on Income and Asset Acquisition in Africa: The Case of Nigeria. World Dev. 2012, 40, 1824-1838. [CrossRef]

20. Christiaensen, L.; Demery, L.; Kuhl, J. The (evolving) role of agriculture in poverty reduction-An empirical perspective. J. Dev. Econ. 2011, 96, 239-254. [CrossRef]

21. Phan, P.V.; O'brien, M.; Mendolia, S.; Paloyo, A. National pro-poor spending programmes and their effect on income inequality and poverty: Evidence from Vietnam. Appl. Econ. 2017, 49, 5579-5590. [CrossRef]

22. Park, A.; Wang, S. Community-based development and poverty alleviation: An evaluation of China's poor village investment program. J. Public Econ. 2010, 94, 790-799. [CrossRef]

23. Araujo, M.C.; Ferreira, F.H.G.; Lanjouw, P.; Özler, B. Local inequality and project choice: Theory and evidence from Ecuador. J. Public Econ. 2008, 92, 1022-1046. [CrossRef]

24. Mansuri, G.; Rao, V. Community-based and-driven development: A critical review. World Bank Res. Obs. 2004, 19, 1-39. [CrossRef] 
25. Wossen, T.; Alene, A.; Abdoulaye, T.; Feleke, S.; Rabbi, I.Y.; Manyong, V. Poverty Reduction Effects of Agricultural Technology Adoption: The Case of Improved Cassava Varieties in Nigeria. J. Agric. Econ. 2018. [CrossRef]

26. Liu, Z.; Rommel, J.; Feng, S. Does it pay to participate in decision-making? Survey evidence on land co-management in Jiangsu Province, China. Ecol. Econ. 2018, 143, 199-209. [CrossRef]

27. Kosec, K.; Wantchekon, L. Can information improve rural governance and service delivery? World Dev. 2018. [CrossRef]

28. He, B. Civic engagement through participatory budgeting in China: Three different logics at work. Public Adm. Dev. 2011, 31, 122-133. [CrossRef]

29. Dai, Y.; Chang, H.H.; Liu, W. Do forest producers benefit from the forest disaster insurance program? Empirical evidence in Fujian Province of China. For. Policy Econ. 2015, 50, 127-133. [CrossRef]

30. Jaramillo, M.; Wright, G.D. Participatory Democracy and Effective Policy: Is There a Link? Evidence from Rural Peru. World Dev. 2015, 66, 280-292. [CrossRef]

31. Lechner, M. Program Heterogeneity and Propensity Score Matching: An Application to the Evaluation of Active Labor Market Policies. Rev. Econ. Stat. 2002, 84, 205-220. [CrossRef]

32. Caliendo, M.; Kopeinig, S. Some practical guidance for the implementation of propensity score matching. J. Econ. Surv. 2008, 22, 31-72. [CrossRef]

33. Mazunda, J.; Shively, G. Measuring the forest and income impacts of forest user group participation under Malawi's Forest Co-management Program. Ecol. Econ. 2015, 119, 262-273. [CrossRef]

34. He, G.; Wang, S. Do College Graduates Serving as Village Officials Help Rural China? Am. Econ. J. Appl. Econ. 2017, 9, 186-215. [CrossRef]

35. Ma, W.; Abdulai, A.; Goetz, R. Agricultural Cooperatives and Investment in Organic Soil Amendments and Chemical Fertilizer in China. Am. J. Agric. Econ. 2018, 100, 502-520. [CrossRef]

36. Schultz, T.W.; Schultz, T.W. Investing in People: The Economics of Population Quality; University of California Press: Berkeley, CA, USA, 1982.

37. Muraoka, R.; Jin, S.Q.; Jayne, T.S. Land access, land rental and food security: Evidence from Kenya. Land Use Policy 2018, 70, 611-622. [CrossRef]

38. Zhang, J.; Giles, J.; Rozelle, S. Does it pay to be a cadre? Estimating the returns to being a local official in rural China. J. Comp. Econ. 2012, 40, 337-356. [CrossRef]

39. Vargas, A.; Lo, A.Y.; Rohde, N.; Howes, M. Background inequality and differential participation in deliberative valuation: Lessons from small-group discussions on forest conservation in Colombia. Ecol. Econ. 2016, 129, 104-111. [CrossRef]

40. Dasgupta, A.; Beard, V.A. Community Driven Development, Collective Action and Elite Capture in Indonesia. Dev. Chang. 2010, 38, 229-249. [CrossRef]

41. Prokopy, L.S. Determinants and benefits of household level participation in rural drinking water projects in India. J. Dev. Stud. 2009, 45, 471-495. [CrossRef]

42. Liu, Z.; Müller, M.; Rommel, J.; Feng, S. Community-based agricultural land consolidation and local elites: Survey evidence from China. J. Rural Stud. 2016, 47, 449-458. [CrossRef]

43. Prokopy, L.S.; Thorsten, R. The Role of Wealth, Income, and Social Capital in Determining a Household's Choice to Participate in Rural Water-Supply Projects in Peru. Environ. Plan. C Gov. Policy 2008, 26, 1162-1176. [CrossRef]

44. Uchida, E.; Rozelle, S.; Xu, J. Conservation Payments, Liquidity Constraints, and Off-Farm Labor: Impact of the Grain-for-Green Program on Rural Households in China. Am. J. Agric. Econ. 2009, 91, 70-86. [CrossRef]

45. Caliendo, M.; Clement, M.; Papies, D.; Scheelkopeinig, S. The Cost Impact of Spam Filters: Measuring the Effect of Information System Technologies in Organizations. Inf. Syst. Res. 2008, 23, 1068-1080. [CrossRef]

46. Cattaneo, M.D. Efficient semiparametric estimation of multi-valued treatment effects under ignorability. J. Econom. 2010, 155, 138-154. [CrossRef]

47. Kamoto, J.; Clarkson, G.; Dorward, P.; Shepherd, D. Doing more harm than good? Community based natural resource management and the neglect of local institutions in policy development. Land Use Policy 2013, 35, 293-301. [CrossRef] 
48. Wilson, G.A.; Hu, Z.; Rahman, S. Community resilience in rural China: The case of Hu Village, Sichuan Province. J. Rural Stud. 2018, 60, 130-140. [CrossRef]

49. Meng, L. Evaluating China's poverty alleviation program: A regression discontinuity approach. J. Public Econ. 2013, 101, 1-11. [CrossRef] 